
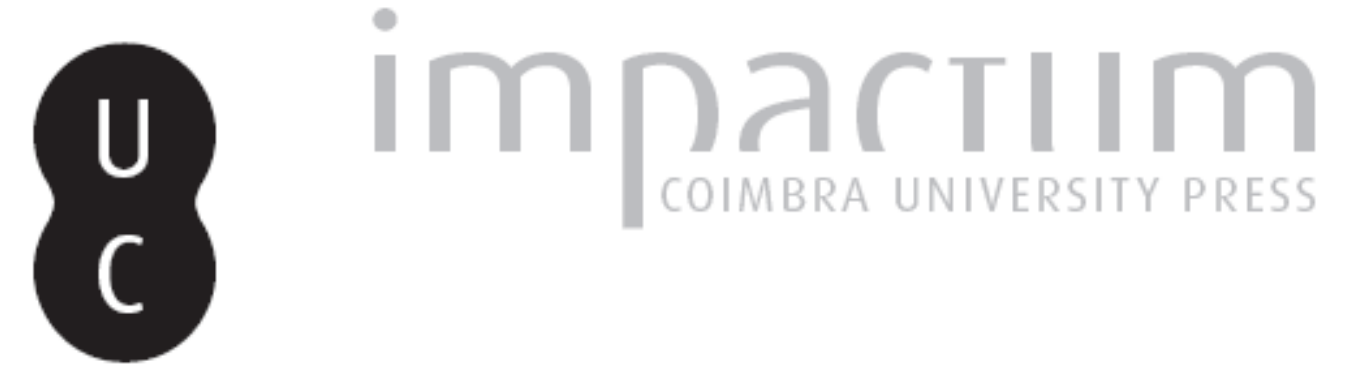

\title{
Sondagem junto ao poço da oficina de salga 1 de Tróia
}

Autor(es): $\quad$ Pinto, Inês Vaz; Magalhães, Ana Patrícia; Brum, Patrícia

Publicado por: Faculdade de Letras da Universidade de Coimbra

URL persistente:

URI:http://hdl.handle.net/10316.2/37864

DOI:

DOI:http://dx.doi.org/10.14195/1647-8657_49_8

Accessed : $\quad$ 26-Apr-2023 10:58:53

A navegação consulta e descarregamento dos títulos inseridos nas Bibliotecas Digitais UC Digitalis, UC Pombalina e UC Impactum, pressupõem a aceitação plena e sem reservas dos Termos e Condições de Uso destas Bibliotecas Digitais, disponíveis em https://digitalis.uc.pt/pt-pt/termos.

Conforme exposto nos referidos Termos e Condições de Uso, o descarregamento de títulos de acesso restrito requer uma licença válida de autorização devendo o utilizador aceder ao(s) documento(s) a partir de um endereço de IP da instituição detentora da supramencionada licença.

Ao utilizador é apenas permitido o descarregamento para uso pessoal, pelo que o emprego do(s) título(s) descarregado(s) para outro fim, designadamente comercial, carece de autorização do respetivo autor ou editor da obra.

Na medida em que todas as obras da UC Digitalis se encontram protegidas pelo Código do Direito de Autor e Direitos Conexos e demais legislação aplicável, toda a cópia, parcial ou total, deste documento, nos casos em que é legalmente admitida, deverá conter ou fazer-se acompanhar por este aviso.

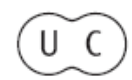


CONIMBRIGA

C)

CN N N

INSTITUTO DE ARQUEOLOGIA

VOLUME XLIX • 2010

FACULDADE DE LETRAS 
INÊS VAZ PINTO

Investigadora do C.E.A.U.C.P. - C.A.M. e Responsável pelas Ruínas Romanas de Tróia.

Ana Patrícia Magalhães e Patrícia Brum

Equipa de arqueologia do troiaresort.

SONDAGEM JUNTO AO POÇO DA OFICINA DE SALGA 1 DE TRÓIA "Conimbriga" XLIX (2010) p. 133-159

RESUMO: Apresentam-se os resultados de uma sondagem realizada na oficina de salga 1 do complexo de produção de preparados de peixe de Tróia, junto à parede sudeste da escadaria de acesso ao poço situado no pátio dessa oficina. Esta sondagem, necessária aos trabalhos de conservação da referida parede do poço, revelou-se uma oportunidade para obter dados sobre a construção do poço e sobre o faseamento da própria oficina. Embora a interpretação dos resultados não seja tão clara quanto seria de desejar, afigura-se como uma evidência que o poço não pertence ao primeiro momento de construção da oficina e que foi construído no século II d.C., ainda na primeira fase de ocupação.

RÉSUMÉ: Dans cet article sont présentés les résultats d'un sondage fait dans l'officine de salaisons $1 \mathrm{du}$ complexe industriel de Tróia, à coté de la paroi sud-est de l'escalier d'accès au puits. Ce sondage, nécessaire aux travaux de conservation de cette paroi, est devenu une opportunité pour obtenir des données sur la construction du puits et sur l'évolution de l'officine. Bien que l'interprétation des résultats ne soit aussi claire qu'on le voudrait, c'est évident que le puits n'appartient pas au premier moment de construction de l'officine et qu'il a été construit au IIe siècle, toujours dans la première phase d'occupation.

Conimbriga, 49 (2010) 133-159 
(Página deixada propositadamente em branco) 


\section{SONDAGEM JUNTO AO POÇO DA OFICINA DE SALGA 1 DE TRÓIA}

\section{Introdução}

A oficina de salga 1 de Tróia foi antes interpretada e apresentada por R. Étienne, Y. Makaroun e F. Mayet (1994) com base na limpeza, análise e desenho das estruturas e duas sondagens feitas dentro de tanques de salga. Esse estudo, parte integrante da primeira monografia dedicada ao complexo de preparados piscícolas de Tróia, procurava fasear e interpretar a diacronia do sítio, e constitui até à data o único instrumento disponível para o entendimento deste importante centro de produção. Os diminutos trabalhos arqueológicos permitiram, apesar de tudo, compreender as três principais fases de construção da oficina 1, ficando, como seria de esperar, diversas questões por investigar.

O projecto de valorização do sítio arqueológico de Tróia, promovido pelo troiaresort, iniciado em 2007, e a necessidade de trabalhos de conservação na oficina 1 motivaram a abertura de uma sondagem junto à parede sudeste da escadaria de acesso ao poço situado no pátio dessa oficina. Essa sondagem permitiu, pela primeira vez, obter dados sobre a construção do poço, cuja apresentação é o objectivo deste estudo.

\section{A oficina de salga 1 de Tróia}

A oficina 1 do complexo de produção de preparados piscícolas de Tróia (fig. 1) foi escavada pela primeira vez por F. Bandeira Ferreira, de 1956 até 1959, no âmbito da missão arqueológica de Tróia promovida por Manuel Heleno, director do Museu Etnológico do Dr. Leite de Vasconcelos (actual Museu Nacional de Arqueologia). A escavação prosseguiu sob a direcção de M. Farinha dos Santos, no início dos anos 
60, mas não foi concluída, desconhecendo-se ainda parte da fiada de tanques nordeste e a parte sudeste, à excepção do tanque situado no canto sul, integrado nas termas. No termo destes trabalhos, ficaram a descoberto dezanove tanques alinhados ao longo de três das paredes da oficina, ficando por escavar o seu lado sudeste.

No início dos anos 90 do século XX, na referida publicação de $\mathrm{R}$. Étienne, Y. Makaroun e F. Mayet (1994), a oficina 1 foi estudada com a designação de usine I. Os trabalhos então efectuados revelaram, em primeiro lugar, que essa oficina estava ligada à oficina 2 por um corredor da fase de construção original, o que significa que ambas pertenciam à mesma fábrica de salga. Nessa primeira fase, a oficina 1 consistia num grande compartimento com pátio central e cetárias à sua volta em três dos lados, talvez dos quatro, com um poço no centro do pátio. Após um curto período de abandono e desmoronamento parcial, a oficina foi subdividida em oficinas mais pequenas (IA, IB, IC e outra por escavar), delimitadas por paredes, e conheceu um novo período de actividade. Houve ainda um terceiro momento de remodelação, visível sobretudo na ruela que se constituiu entre a oficina IB e os outros espaços da oficina.

Os trabalhos realizados permitiram datar o final da primeira fase de actividade da oficina no final do século II ou início do III. Na ausência de dados concretos para a reactivação das oficinas no século III, propôs-se que tenha tido lugar desde o primeiro quartel desse século (Étienne, Makaroun e Mayet, 1994, p. 82).

$\mathrm{O}$ abandono definitivo da produção de salgas nessa oficina foi datado dos meados do século $\mathrm{V}$, data essa que foi confirmada pelo estudo da terra sigillata de Tróia existente no Museu Nacional de Arqueologia (Étienne, Makaroun e Mayet, 1994, p. 39-49).

No que respeita ao início da ocupação romana em Tróia, na ausência de dados estratigráficos, o referido estudo da terra sigillata de Tróia disponível no Museu Nacional de Arqueologia levou os autores a situá-lo no reinado de Cláudio, nos meados do século I (Étienne, Makaroun e Mayet, 1994, p. 30).

Os trabalhos realizados desde 2007 pelas signatárias, no âmbito do projecto de valorização das ruínas romanas de Tróia, permitiram confirmar a pertinência dos resultados dos trabalhos de R. Étienne, Y. Makaroun e F. Mayet, mas trouxeram algumas precisões.

$\mathrm{Na}$ escavação de uma área exterior à oficina 2 , junto à sua parede nordeste, sob vários níveis mais tardios, foi identificado um contexto que permite recuar a construção da fábrica de salga que englobava as 
oficinas 1 e 2, e consequentemente a ocupação de Tróia, até à época de Tibério, ou seja, até ao segundo quartel do século I d. C (Pinto, Magalhães e Brum, 2011).

No que se refere ao abandono da produção, e consequentemente ao abandono das próprias oficinas, a grande quantidade e homogeneidade do material cerâmico recolhido numa lixeira a sudeste do poço da oficina 1 permitiu concluir que a produção terá perdurado apenas até ao final do primeiro terço do século V (Pinto, Magalhães e Brum, no prelo).

Quando se iniciaram os trabalhos preparatórios do projecto de valorização das ruínas de Tróia em 2007, a parede sudeste da escadaria de acesso ao poço suportava o peso da grande duna de areia situada a sudeste. Apesar de desafogada no passado (fig. 2), o deslizamento das areias voltou a cobrir a área a sudeste e a pressionar a parede, causando o desligamento de vários dos seus elementos.

Para libertar a oficina 1 da pressão das areias, em 2008 e 2009 fez-se uma grande operação de desafogamento e escavação da área sudeste, que revelou vários níveis de lixeira entremeados com camadas de areia, e estratos de derrube sobre o último piso da oficina. No entanto, estes trabalhos revelaram-se insuficientes à protecção do poço e o projecto de conservação e restauro elaborado para a recuperação dessa parede implicava a abertura de uma vala junto a essa parede para instalação de um muro de gabiões que aliviasse a parede da pressão das areias a sudeste.

Por conseguinte, o objectivo principal da sondagem aqui descrita foi a conservação e o restauro da parede do poço. No entanto, a vala necessária a esses trabalhos exigia, pela sua localização, um cuidadoso trabalho de escavação e revelava-se como uma oportunidade para obter novos dados sobre a construção do poço e o faseamento da oficina 1.

\section{O poço de mergulho}

O poço de mergulho da oficina 1, publicado pela primeira vez em 1994 (Étienne, Makaroun e Mayet, 1994, p. 73), fica situado na parte central do pátio da oficina mas levemente descentrado, estando mais chegado a noroeste (fig. 3). É composto pela estrutura circular do poço propriamente dito e por uma escadaria de acesso formada por degraus de tamanho irregular, ladeada por paredes com cerca de $6,75 \mathrm{~m}$ de comprimento e formando, com o poço, uma caixa com cerca de 
$8,90 \mathrm{~m}$ de comprimento, largura no topo da escadaria, a nordeste, de $2,38 \mathrm{~m}$ e a sudoeste de $1,86 \mathrm{~m}$. A altura máxima visível, na base da escadaria, é de $2,90 \mathrm{~m}$. Esta escadaria dá acesso ao interior do poço através de um arco. Ao lado sudeste do poço encosta uma cisterna de formato rectangular, com $3 \mathrm{~m}$ por 2,60 m, revestida a opus signinum.

A cuidadosa observação das estruturas que formam o poço e a sua escadaria indica que correspondem a uma única fase de construção.

\section{Sondagem junto à parede do poço (figs. 4-6)}

Com a designação de Sondagem $B$, na sequência alfabética das sondagens realizadas no âmbito dos trabalhos preparatórios da valorização das ruínas de Tróia em 2010, foi aberta uma sondagem junto à parede sudeste da escadaria do poço de mergulho do pátio da oficina $1 \mathrm{com}$ $6,70 \mathrm{~m}$ de comprimento ao longo da parede do poço e 2,50 $\mathrm{m}$ de largura (fig. 3 e 7).

A primeira unidade estratigráfica (u.e.) definida foi o piso argiloso [490], que parece apontar para os meados/finais do século IV mas que pode abarcar a primeira metade do século $\mathrm{V}$, de acordo com um fragmento de terra sigillata africana D (D1), da forma Hayes 67B ( $\mathrm{n}^{\circ}$ 1, Est. I) (Bonifay, 2004, p. 173). Com efeito, esta unidade revelou um conjunto pouco homogéneo de materiais, com ânforas da forma Almagro $51 \mathrm{c}\left(\mathrm{n}^{\circ}\right.$ 2, Est. I), tanto da variante B ( $\mathrm{n}^{\mathrm{o}} 3$, Est. I) (de meados do século III a meados do IV) como da variante $\mathrm{C}$ (de meados do século IV até um momento indeterminado do século V, não ilustrada) (Étienne e Mayet, 2002, p. 145-147); outras ânforas regionais como a Keay 78/Sado 1, variante B (nº 4, Est. I ) (Keay, 1984, p. 373, no 3; Étienne e Mayet, 2002, p. 149-151); uma provável Lusitana 10 (n ${ }^{\circ}$ 5, Est. I) (Diogo, 1987, p.184), de cronologia pouco definida mas presente nos níveis de abandono do século V na oficina 2; e ânforas africanas, a primeira da forma Africana I, variante tardia $\left(\mathrm{n}^{\mathrm{o}} 6\right.$, Est. I), datada da segunda metade do século III-século IV (Bonifay, 2004, p. 106-107), uma da forma Keay $25.2\left(\mathrm{n}^{\mathrm{o}}\right.$ 7, Est. I) e outra da forma Keay $25.3\left(\mathrm{n}^{\mathrm{o}}\right.$ 8, Est. I), formas típicas do século IV, e a Keay 25.2 ainda da primeira metade do século V (Bonifay, 2004, p. 119-122). O fundo $n^{\circ} 9$ (Est. I) pertence possivelmente a uma "spatheion" igualmente tardia, não anterior ao século V (Bonifay, 2004, p. 125) e outras peças são claramente residuais, integradas nas formas Dressel 14 e Dressel 14 tardia (século I a inícios 
do III) (Étienne e Mayet, 2002, p. 134-135). Na cerâmica comum, pouco abundante, destaca-se um almofariz IV-E-3 na tipologia de S. Cucufate $\left(\mathrm{n}^{\mathrm{o}} 10\right.$, Est. I) uma forma típica do Baixo Império (Pinto, 2003, p. 278).

A unidade [715], um sedimento arenoso com seixos, era restrita ao limite sudoeste da sondagem, sob o piso [490], e tinha pouco material, datável do século III/IV.

A u.e. [719], identificada sob as u.e.'s [490] e [715], era provavelmente o nível de preparação do piso [490], genericamente integrada no século IV pela presença de duas peças classificáveis de terra sigillata africana D (D1), uma da forma Hayes 59A (nº 1, Est. II) (Hayes, 1972, p. 100; Atlante I, 1981, p. 83; Mackensen, 1993, p. 339 a 401), e outra da forma Hayes 58 ( $\mathrm{n}^{\mathrm{o}}$ 2, Est. II), muito diminuta para atribuição a alguma das variantes indicadas por Hayes (1972, p. 96; Atlante I, 1981, p. 82), e a única ânfora classificável era um bordo da forma Keay 25.1 (nº 3, Est. II) (Bonifay, 2004, p. 119).

A u.e. [721] seria um piso de argamassa, contendo alguma cerâmica para endurecer a sua superfície, que não se estendia a toda a sondagem, parecendo ter sido destruído no limite sudoeste. Este piso continha material cerâmico cronologicamente pouco homogéneo, datável de finais do século III a meados do século IV, destacando-se três peças de terra sigillata africana $\mathrm{C}$ (um em C1/2 e outros dois em C tardia), um da forma Hayes 58A ( ${ }^{\circ}$ 4, Est. II) (Hayes, 1972, p. 96; Atlante I, 1981, p. 118), e outros dois da forma Hayes $50 \mathrm{~A} / \mathrm{B}$ (n ${ }^{\circ} 5$, Est. II) (Hayes, 1972, p. 73). Os exemplares recolhidos em terra sigillata africana $\mathrm{D}$ eram minoritários, com apenas um fragmento diminuto em D1 classificável na forma Hayes 58. As ânforas vêm confirmar esta datação pois sendo a mais abundante a Almagro 51c, com nove bordos ( $\mathrm{n}^{\circ}$ 6-8, Est. II), os três fundos, de fabrico regional, são da variante B ( $\mathrm{n}^{\circ}$ 9, Est. II). Registaram-se outras ânforas lusitanas, Dressel 14, Dressel 14 tardia, uma possível imitação de Dressel 7-11 e um fundo de Keay 78/Sado 1, ânforas béticas das formas Almagro 50 (n ${ }^{\circ} 10-11$, Est. II) (Étienne e Mayet, 2002, p. 137) e Almagro 51c (Étienne e Mayet, 2002, p. 145-147) e ânforas africanas representadas por um bordo provavelmente de Tripolitana III (séculos III-IV) $\left(\mathrm{n}^{\circ} 12\right.$, Est. II) e por dois fundos de Africana II ou III (Bonifay, 2004, p. 105 e 119). A cerâmica comum é pouco significativa em termos cronológicos.

A camada argilosa [722], que se estendia sob as u.e.'s [721] e [719] (no limite sudoeste da sondagem, onde o piso [721] se encontrava destruído), terá sido o primeiro piso à volta do poço após a reactivação 
da produção, feito no momento da segmentação da grande oficina noutras mais pequenas. Foram identificados nesta unidade sete fragmentos de terra sigillata, dois de produção sudgálica, três de terra sigillata africana, fabrico $\mathrm{A}$, e outros dois de fabrico $\mathrm{C}$, embora um de classificação duvidosa. Destes exemplares, foi apenas possível classificar um fragmento de bordo de terra sigillata sudgálica no tipo Dragendorff $15 / 17$, que começa a ser produzida nos inícios do século I e se pode estender até ao período flávio (Polak, 2000, p. 82 a 87), e outro fragmento de bordo de terra sigillata africana A (A2) foi integrado na forma Hayes 14, variante A ( ${ }^{\circ} 1$, Est. III), de finais do século II a inícios do século III (Bonifay, 2004, p. 159). As ânforas são também de formas diversas, sendo a mais abundante a Almagro 51c, variante $B$ ( $n^{\circ} 2-3$, Est. III), e não se verificando, mais uma vez, exemplares da variante $C$. Outras ânforas são a Dressel 14, variante C, bem representada por cinco bordos ( $\mathrm{n}^{\circ} 4$, Est. III), uma possível Dressel 14 tardia (n ${ }^{\circ} 5$, Est. III), uma Almagro 50 de fabrico regional (Mayet e Silva, 1998, p. 148), um arranque de asa de Dressel 20, um bordo de Beltrán IIB ( $\mathrm{n}^{\circ}$ 6, Est. III) (Étienne e Mayet, 2002, p. 129) e um fundo de Almagro 50 de pasta clara bética ( ${ }^{\circ} 7$, Est. III). Recolheram-se ainda três fragmentos de opérculos e cerâmica comum, destacando-se uma caçarola de fabrico africano Hayes $23\left(\mathrm{n}^{\circ}\right.$ 8 , Est. III), uma forma típica do século II que pode ir até inícios do III (Hayes, 1972, p. 45-48). A presença da ânfora Almagro 51c, variante $\mathrm{B}$ indica uma datação a partir de meados do século III até à primeira metade do século IV, ou ainda do segundo quartel do século III, caso se venha a comprovar que esta ânfora já era produzida nesse período (Mayet e Silva, 1998, p. 142). Aliás, tendo em conta que a maioria dos materiais desta unidade são do século II e primeira metade do século III, é mais provável uma datação no segundo quartel desse século, o que sugere que o piso [722] tenha sido construído no âmbito da segmentação da grande oficina noutras mais pequenas.

No limite sudoeste da sondagem foi definida a u.e. [737], uma vala irregular que cortava a u.e. [738] (Fig. 8), sob o piso [722], um piso mais antigo formado por um sedimento argiloso endurecido. Esta vala foi criada para conter uma sepultura encostada à parede da escadaria do poço e foi preenchida por um sedimento areno-argiloso, u.e. [747] (fig. 7b), que continha um bordo de Almagro 50/Keay XVI A de pasta clara bética, datável desde os finais do século II (Keay, 1984, p. 151).

Sob o sedimento [747], a vala [737] já tinha sido preenchida pelo sedimento [754], que aproveitou o espaço de uma outra vala pré-existente 
([761]). Na unidade [754] foi identificado um fragmento de bojo com meia-cana que pode corresponder à forma Drag. 15/17 ou Drag. 16 de terra sigillata sudgálica, tipos presentes desde os inícios do século I até ao período flávio, ou mais precisamente entre o principado de Tibério e o de Nero na segunda hipótese (Polak, 2000, p. 82 a 87), dois fragmentos de terra sigillata africana A (A2), uma aba encurvada entre as formas Hayes 2, de período flávio, ou Hayes 3, que pode atingir os meados do século II (Hayes, 1972, p. 21 a 25), ou mesmo o século III (Atlante I, 1981, p. 24), e um bordo da forma Hayes 27 (nº 9, Est. IV), genericamente datada entre a segunda metade do século II e a primeira metade do século III (1981, p. 31-32; Bonifay, 2004, p. 159), e ainda alguns bojos de ânfora regional e de cerâmica comum. Estes materiais apontam para uma cronologia do século II até à primeira metade do século III d.C., datando o momento de construção da sepultura.

A sepultura, já violada e sem cobertura, estava preenchida por um sedimento areno-argiloso que se pode dividir em camada superior ([735]) e camada inferior ([736]), esta com uma elevada concentração de argamassas parecendo resultar da destruição das paredes da sepultura, contendo um fragmento de bordo de Almagro 51c ( $\mathrm{n}^{\circ}$ 9, Est. III). Esta camada cobria um esqueleto humano juvenil, em bom estado de conservação, com idade provável entre os 10 e os 11 anos, em posição de decúbito dorsal, com uma concha junto a um dos braços, e orientado de noroeste para sudeste (fig. 9). ${ }^{1}$ Assentava na u.e. [752] semelhante à do enchimento da sepultura.

Tendo em conta que a u.e. [738] foi cortada pela vala [737] com a sepultura construída no período de abandono, e que cobre as camadas associadas à construção do poço, deduz-se que a unidade [752] é o piso que se formou à volta do poço após a sua construção. Segundo esta lógica, será esta camada que datará a construção do poço. Nesta unidade recolheram-se poucos materiais, que correspondem a tipos e cronologias muito diversas, com a presença de dois fragmentos sem forma de fabrico hispânico de Andújar, e de terra sigillata do sul da Gália, representada pelas formas Drag. 27 e 24/25 (nº 10, Est. III), que entram em circulação desde o final do principado de Augusto e se podem prolongar até 120/130 (Polak, 2000, p. 117 a 121), e um fundo com a marca MAR, possivelmente da forma Drag. 18 ( $\mathrm{n}^{\mathrm{o}}$ 11, Est. III), que

1 O esqueleto identificado na sondagem B foi escavado pela arqueóloga, mestre em Antropologia, Margarida Figueiredo.

Conimbriga, 49 (2010) 133-159 
acompanha todo o período de exportação de La Graufesenque, entre 10 e 120 d.C. (Polak, 2000, p. 91), período esse afinado pela leitura da marca com nexo $(\mathrm{M}=\mathrm{A}) \mathrm{MAR}[\ldots]$. Esta marca de oleiro está incompleta e por isso pode corresponder a Marinus (ex. M25-27, plate 13), que laborou de 45 a 110 d.C., a Marsus (M28-39, plate 13), com peças datadas entre 40 e 80 e também a Martialis (M31-32, plate 13), que produziu peças desde o principado de Nero até aos inícios do período flávio (c. 55 a 80) (Polak, 2000, p. 261 e 262). Estas marcas apontam para uma datação centrada em meados do século I, mas recentemente foram propostas outras datações que prolongaram o período de produção destes oleiros, admitindo-se um intervalo cronológico entre 50 e 150/170, no caso da marca Marinus, (Genin, 2007, p. 265, $\mathrm{n}^{\circ} 260$ ), entre 50 a 100, no caso da marca Martialis (Genin, 2007, p. 266, $\mathrm{n}^{\circ}$ 262), mas restringindo a produção do oleiro Marsus ao período entre 50 e 80 d.C. (Genin, 2007 , p. 266, $\left.\mathrm{n}^{\mathrm{o}} 261\right)$. Foi ainda identificada a ânfora regional Dressel 14 , representada pelas variantes B $\left(\mathrm{n}^{\mathrm{o}} 12\right.$, Est. III) e C ( $\mathrm{n}^{\mathrm{o}} 13$, Est. III) e por fundos de variante indefinida ( $\mathrm{n}^{\circ} 14$, Est. III), asas e opérculos. Um fragmento de asa em fita de Dressel 14, pelas suas dimensões, só pode pertencer a uma Dressel 14 tardia, mas mesmo considerando que possa ser uma intrusão no piso argiloso, a datação deste piso não pode ser anterior ao século II, tendo em conta a presença da ânfora Dressel 14 , variante $\mathrm{C}$.

A u.e. [749] é outra camada argilosa endurecida, imediatamente sob o piso [738], que encostava à parede da escadaria do poço e tudo indica que foi um enchimento posterior à sua construção, sendo por isso, talvez ainda mais do que a camada superior [738], um indicador importante da data de construção do poço. As peças datáveis nela recolhidas são um bordo de terra sigillata de tipo itálico ( ${ }^{\circ} 1$, Est. IV), da forma Atlante XIV (tav. CXXIII, no 16) (Pucci, 1985, p. 387) que corresponde ao tipo 8.1.1 do Conspectus, (1990, p. 66), um fundo de Dressel $14\left(\mathrm{n}^{\mathrm{o}} 2\right.$, Est. IV) e um bordo de ânfora da forma Dressel 20 (n ${ }^{\circ}$ 3, Est. IV), de época antonina (Berni, 1998, p. 45), muito provavelmente da época de Adriano (informação pessoal de P. Berni), que confirma a construção do poço no século II, provavelmente na primeira metade deste século.

As u.e's [748] e [751] são depósitos de interpretação pouco clara e sem indicadores cronológicos significativos.

A u.e. [755] era argilosa e endurecida, tal como as u.e.'s [749] e [751] sob as quais se estendia, e revelou um pequeno conjunto de materiais datável do século I composto por terra sigillata, ânforas e 
cerâmica comum. A terra sigillata é de tipo gálico, tendo-se identificado três fundos com marca de oleiro, embora um preservasse apenas o início da cartela. Estes fundos são de fabrico sudgálico, lendo-se o nome do oleiro LICINIMO ( $\mathrm{n}^{\mathrm{o}}$ 4, Est. IV), com paralelo idêntico na marca L17 da oficina de Licinus na obra de M. Polak, datada entre 50 e 70 d.C. (2000, p. 252 , plate 12$)$, e noutro fragmento a marca incompleta e com as letras pouco nítidas [...]LIIIIXI ( $\mathrm{n}^{\circ}$ 5, fig. 10), de leitura mais problemática, podendo corresponder à oficina de Felix, com o desdobramento FILIIIIXI, dos tipos F21-23 de Polak (2000, p. 225 e 226, plate 9), em actividade entre 45 e 80 d.C., ou um caso semelhante ao tipo F25 de Polak, interpretada como FIILI.XSI, e datada de 45 a 70 d.C. (2000, p. 226, plate 9). A leitura destas marcas aponta assim para uma datação centrada em meados do século I, mas já foi admitida uma datação mais avançada para ambas as marcas em La Graufesenque. A marca correspondente a Licinus (LICINVS) pode ser situada entre 50 e 100/110 (Genin, 2007, p. 265, $\mathrm{n}^{\mathrm{o}} 238$ ) e a de Felix (FELIX II), entre 50-150/170 (Genin, 2007, p. 264, $\mathrm{n}^{\circ}$ 172). O fragmento de bojo decorado é da forma Drag. 30, apresentando um fabrico gálico atípico, $\left(\mathrm{n}^{\circ} 6\right.$, Est. IV). Esta forma de taça cilíndrica decorada começa a ser produzida a partir da segunda década do século I até meados do século II (Oswald e Pryce, 1966, p. 87). As ânforas são da forma Dressel 14, variante B, embora próximas da $\mathrm{C}\left(\mathrm{n}^{\mathrm{o}} 7\right.$ e 8 , Est. IV).

As valas [758] e [761] cortavam a U.E. [759] e são ambas de funcionalidade desconhecida. Um alinhamento de pedras de diferentes dimensões, essencialmente grandes, u.e. [753], acompanhava os limites da vala [761], parecendo estruturar os seus limites, e continha um sedimento argiloso, u.e. [760], sem cerâmica.

A u.e. [759] é um nível espesso de areias amareladas, identificado sob [755], que se pensou, a princípio, corresponder ao substrato original. Nestas areias recolheu-se algum material datável, nomeadamente uma peça de terra sigillata de fabrico sudgálico ( $\mathrm{n}^{\circ} 10$, Est. IV) da forma Drag. 24/25, forma produzida num período de tempo relativamente amplo, situado entre o século I e os inícios do II (Polak, 2000, p. 117 a 121) mas apresentando características típicas da época de Cláudio, um bordo de ânfora Dressel 14 da variante A ( $\mathrm{n}^{\circ} 1$, Est. V), dois fundos $\left(\mathrm{n}^{\mathrm{o}} 2\right.$, Est. V) e três asas da mesma forma e vários fragmentos de um bordo e um fundo inegavelmente da forma Dressel 14 tardia $\left(n^{\circ} 3\right.$ e 4 , Est. V), este último com grafito. Outro bordo $\left(\mathrm{n}^{\circ} 5\right.$, Est. V) poderá ser de uma Dressel 14, variante B, bastante pequena ou também de uma 
Dressel 14 tardia. A presença de Dressel 14 tardia obrigaria a retardar a construção do poço para o final do século II, mas acontece que os fragmentos dessa ânfora foram recolhidos perto da vala [737], podendo ser uma contaminação do momento da construção da sepultura.

$\mathrm{Na}$ escavação da u.e. [759] identificaram-se algumas manchas finas de argila, que se concentraram na base, o que justificou a individualização de uma unidade onde a argila se encontrava mais concentrada, u.e. [762], que não foi completamente escavada porque a sondagem B já não oferecia condições de segurança. Será muito provavelmente equivalente à u.e. [756], correspondendo ao mesmo momento de separação entre as areias redepositadas da u.e. [759] após a construção do poço e as areias do substracto original [764], identificadas no final da escavação da sondagem.

Só no final da escavação, com a identificação desta última unidade e observando melhor os cortes existentes na sondagem, é que nos apercebemos de que a orientação geral das unidades pressupõe que terá sido realizado um corte na duna preexistente, com um interface de sentido descendente de nordeste para sudoeste, para a fundação da escadaria de acesso ao poço de mergulho (fig. 4 e 5). A vala escavada, u.e. [763], terá sido compactada pela colocação das argilas das unidades [762] e [756] e em seguida pelas areias [759], que colmataram a vala para fundação do muro, apoiando os degraus e a parede sudeste que assentavam directamente sobre a sua superfície.

A parede sudeste da escadaria de acesso ao poço tinha a base mais larga, até uma altura de $1,80 \mathrm{~m}$, feita com pedras unidas por um ligante argiloso. A parte superior era feita com argamassa e o seu topo está restaurado com argamassa à base de cimento (fig. 10).

\section{Interpretação}

Os contextos estratigráficos desta sondagem surpreendem pela heterogeneidade cronológica dos seus materiais, contrastando com a homogeneidade que tem sido verificada nos enchimentos de cetárias e níveis de lixeira recentemente escavados nas oficinas 1 e 2 (Pinto, Magalhães e Brum, 2010 e no prelo). A explicação está certamente nos processos de formação bem diversos destes níveis de piso. Com efeito, a natureza arenosa do substrato desta área obrigava a que a terra argilosa fosse trazida de fora. A heterogeneidade dos materiais que continham 
mostra que essas terras foram trazidas de outros pontos do aglomerado urbano com lixo de vários momentos.

R. Étienne, Y. Makaroun e F. Mayet (1994, p. 73) consideraram, sem qualquer hesitação, que o poço pertencia à primeira fase da oficina, e uma simples análise da relação do poço com as estruturas envolventes comprova-o, visto a parede sudeste da oficina $1 \mathrm{~A}$ ter sido implantada muito próxima dele, não dando espaço suficiente para a sua construção, tendo em conta a sua profundidade. Isto é ainda reforçado pela construção de uma sepultura, encostada à parede da escadaria do poço, que só pode datar do período de abandono entre a primeira e a segunda fase de actividade.

A escavação mostrou que o poço foi construído dentro de uma vala escavada e preenchida por níveis de areia e de terras argilosas e que o piso que se formou após a sua construção só pode ser aquele que foi designado por unidade [738], no qual foi posteriormente escavada uma vala para construir uma sepultura. Nas camadas de preenchimento da vala, até à formação do piso [738], sobressai a relativa abundância de cerâmica do século I, inícios do século II, com vários fragmentos de terra sigillata sudgálica com marcas. No entanto, nas principais camadas aparece também material do século II, nomeadamente a ânfora Dressel 14, variante C e uma ânfora Dressel 20 da época de Adriano, que indicam que a construção do poço se realizou nesse século. Tendo em conta a referida abundância de material antigo e a datação da Dressel 20, é provável que essa construção tenha sido levada a cabo na primeira metade do século II.

A total ausência de vestígios do pavimento da primeira fase da oficina explicar-se-á pela sua destruição na área da sondagem para se escavar a vala para a construção do poço. Fica por resolver a discrepância entre a cota apontada para o piso da primeira fase $(4,40 \mathrm{~m})$ (Étienne, Makaroun e Mayet, 1994, p. 72) e a cota de 3,80 m do piso [738].

A inesperada sepultura encostada à parede do poço materializa e comprova o período de interrupção da actividade constatado por R. Étienne, Y. Makaroun e F. Mayet (1994, p. 70). O enchimento da sepultura violada, e o piso [722] que a cobre, testemunham a reactivação da oficina, agora segmentada, após o período de interrupção da produção. Tal como acima foi fundamentado, essa reactivação poderá ter tido lugar em meados do século III, ou ainda no segundo quartel desse século.

O piso de argamassa [721], que se sobrepôs ao [722], tem uma datação não anterior aos finais do século III, devido à presença de terra 
sigillata africana $\mathrm{D}$, e não posterior aos meados do século IV, tendo em conta a ausência das formas de terra sigillata típicas de finais desse século e também da variante $C$ da ânfora Almagro 51c.

Se o piso [722] corresponde ao momento de reactivação da produção, o [721] poderá datar do segundo momento de remodelação da oficina, que criou uma ruela entre a oficina $1 \mathrm{~A}$ e a oficina $1 \mathrm{~B}$ dando acesso ao poço, e que R. Étienne, Y. Makaroun e F. Mayet (1994, p. 88) situaram aproximadamente na primeira metade do século IV.

A camada [719], tendo em conta a sua fraca compactação, será de preparação do piso superior e o piso [490] será o último do pátio da oficina, tendo na sua composição materiais que apontam para uma datação de finais do século IV ou inícios do século V.

A comparação destes dados com aqueles que resultaram de trabalhos recentes na oficina 2 sugere que as oficinas 1 e 2 não terão coincidido nos momentos de retoma da produção e remodelação após a interrupção de finais do século II, inícios do século III. Com efeito, a reactivação da oficina 2 é testemunhada pelo pavimento da nova oficina $2 \mathrm{~B}$, com muitos fragmentos de cerâmica, sobretudo de ânfora Dressel 14 mas também de Almagro 50, estando a ânfora Almagro 51c ausente, enquanto a primeira remodelação da oficina 1 já apresenta Almagro 51c. No entanto, embora com um leve desfasamento, ambos se poderão situar na primeira metade do século III. No segundo momento de remodelação, o desfasamento é maior visto que na oficina 2 se propôs que não ultrapassasse os meados do século III enquanto que na oficina 1 o piso [721] não é anterior aos finais do século III.

Por último, se o poço só foi construído no século II, como se abastecia a oficina 1 de água no século I? Provavelmente no poço imediatamente a sudeste das termas que tem vestígios de ter tido uma escadaria de acesso na sua primeira fase e que terá sido remodelado antes da construção da palaestra desse edíficio, no século III.

\section{Conclusão}

A escavação da sondagem aberta junto à parede sudeste da escadaria do poço tem como grande novidade a evidência de que o poço do pátio da oficina 1 não pertence ao plano de construção original da oficina e só foi construído no século II, provavelmente na primeira metade desse século. Embora não permita uma grande precisão cronológica, a estratigrafia 
da sondagem comprova as principais conclusões da interpretação da oficina de R. Étienne, Y. Makaroun e F. Mayet publicadas em 1994, nomeadamente que o poço pertence à primeira fase de ocupação, que houve um período de efectivo abandono da oficina no final do século II ou início do século III, que a segunda fase de ocupação data de pleno século III e que a terceira fase de ocupação pode datar da primeira metade do século IV, não sendo anterior a finais do III. A sondagem revelou ainda um piso dos finais do século IV, inícios do V que corresponderá a uma última fase de ocupação dessa área da oficina.

\section{Bibliografia}

Atlante I = CARANDINI, A. et al. (1981) - Ceramica Africana. In CARANDINI, A. (coord.) - Atlante delle forme ceramiche, I. Ceramica fine romana nel Bacino Mediterraneo (medio e tardo impero). Enciclopedia dell'Arte Antica Classica e Orientale. Roma, p. 9-227.

BERNI MILLET, P. (1998) - Las ánforas de aceite de la Bética y su presencia en la Cataluña romana, Barcelona : Collecció Instrumenta 4.

BONIFAY, M. (2004) - Études sur la céramique romaine tardive d'Afrique. Oxford: BAR International Series 1301.

Conspectus $=$ ETTLINGER, E. et al. (1990-2002) - Conspectus formarum terrae sigillatae italico modo confectae. Bona: Dr. Rudolf Habelt GMBH (Materialen zur romisch-germanischen Keramik; Heft 10).

DIOGO, A. M. D. (1987) - "Quadro tipológico das ânforas de fabrico lusitano”. $O$ Arqueólogo Português Série IV 5 179-191.

ÉTIENNE, R. ; MAKAROUN, Y. ; MAYET, F. (1994) - Un grand complexe industriel à Tróia (Portugal). Paris: E. de Boccard.

ÉTIENNE, R.; MAYET, F. (2002) - Salaisons et sauces de poisson hispaniques. Paris: É. de Boccard.

GENIN, M. et al. (2007) - La Graufesenque (Millau, Aveyron), Vol. II. Sigillées lisses et autres productions. Pessac: Éditions de la Féderation Aquitania.

HAYES, J. W. (1972) - Late Roman pottery. Londres: The British School at Rome.

KEAY, S. (1984) - Late Roman Amphorae in the Western Mediterranean. A typology and economic study: the Catalan evidence. BAR International Series 196.

MACKENSEN, M. (1993) - Die spatantiken Sigillata-und Lampentopferein von El Mahrine (Noordtunesien). Studien zur Nordafrikanischen Feinkeramik des 4. Bis 7. Jahrhunderts (mit einem Beitrag von Sebastien Storz). 2 vols. Munique: C. H. Beck' sche Verlagsbuchhandlung (Muncher Beitrage zur Vor-und Frugeschichte; 50).

MAYET, F.; SILVA, C. T. (1998) - L'atelier d'amphores de Pinheiro (Portugal). Paris: E. de Boccard.

Conimbriga, 49 (2010) 133-159 
MAYET, F.; SILVA, C. T. (2002) - L'atelier d'amphores d'Abul (Portugal). Paris: E. de Boccard.

OSWALD, F.; PRYCE, D. (1966) - An Introduction to the Study of Terra Sigillata. Londres.

PINTO, I.V. (2003) - A cerâmica comum das villae romanas de São Cucufate (Beja). Lisboa: Universidade Lusíada.

PINTO, I.V.; MAGALHÃES, A. P.; BRUM, P. (2010) - "Ceramic assemblages from a fish-salting factory in Tróia (Portugal)". Rei Cretariae Romanae Fautorum Acta 41 529-537. Bona

PINTO, I.V.; MAGALHÃES, A. P.; BRUM, P. (2011) - "O complexo industrial de Tróia desde os tempos dos Cornelii Bocchii”. In CARDOSO, J. L. e ALMAGROGORBEA, M. (eds.) - Lucius Cornelius Bocchus, Escritor Lusitano da Idade de Prata da Literatura Latina. Colóquio Internacional de Tróia, 6-8 de Outubro de 2010. Lisboa-Madrid, p. 133-167.

PINTO, I.V.; MAGALHÃES, A. P.; BRUM, P. (no prelo) - "Un dépotoir du Ve siècle dans l'officine de salaisons 1 de Tróia, Portugal". Rei Cretariae Romanae Fautorum Acta 42.

POLAK, M. (2000) - South gaulish terra sigillata from Vechten. Nijmegen: Rei Cretariae Romanae Fautorum Acta - Supplementum 9.

PUCCI, G. (1985) - Terra sigillata italica. In CARANDINI, A. (coord.) - Atlante delle forme ceramiche, II, Ceramica fine romana nel Bacino Mediterraneo (tardo elenismo e primo impero). Enciclopedia dell'Arte Antica Classica e Orientale. Roma, p. 361-404. 


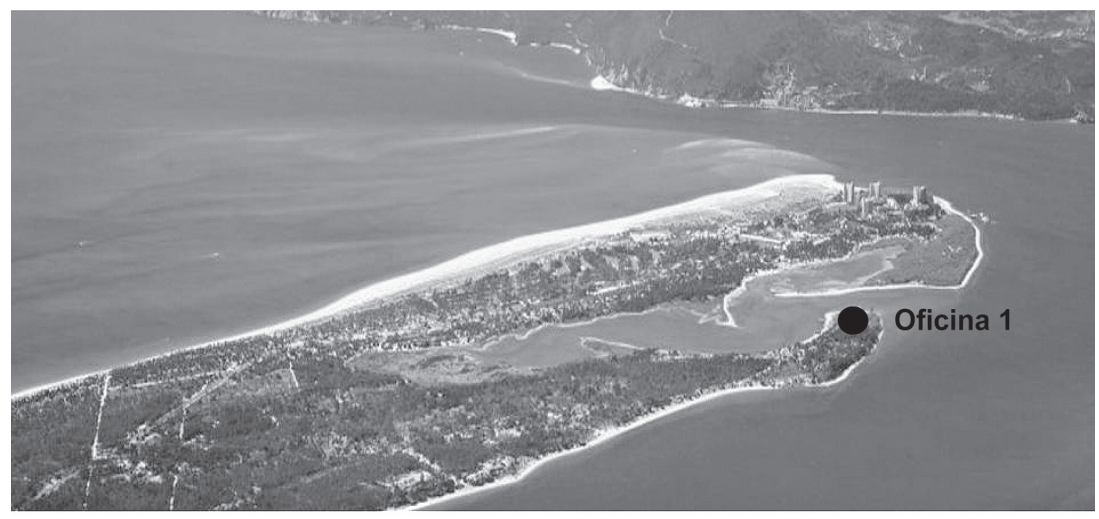

FIG. 1. Localização da oficina 1 na península de Tróia.

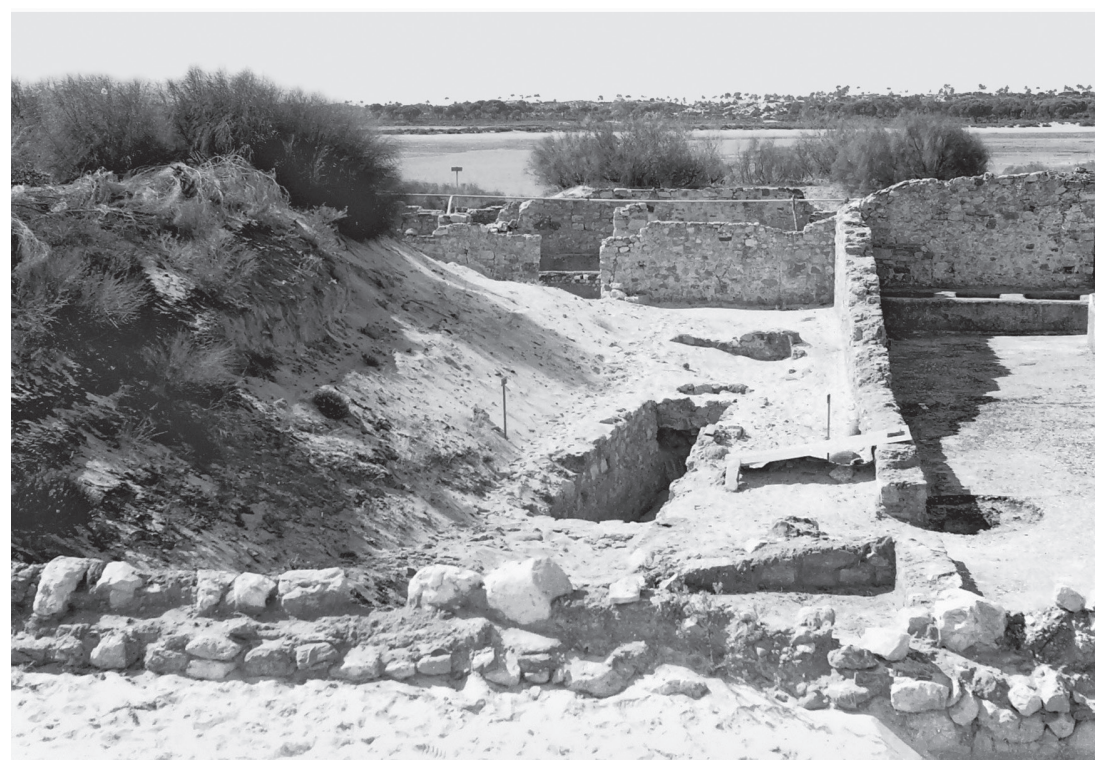

Fig. 2. Fotografia dos inicios dos anos 60 do séc. XX de M. Farinha dos Santos (Arquivo fotográfico do Prof. M. Farinha dos Santos cedido por João Luís Cardoso). 


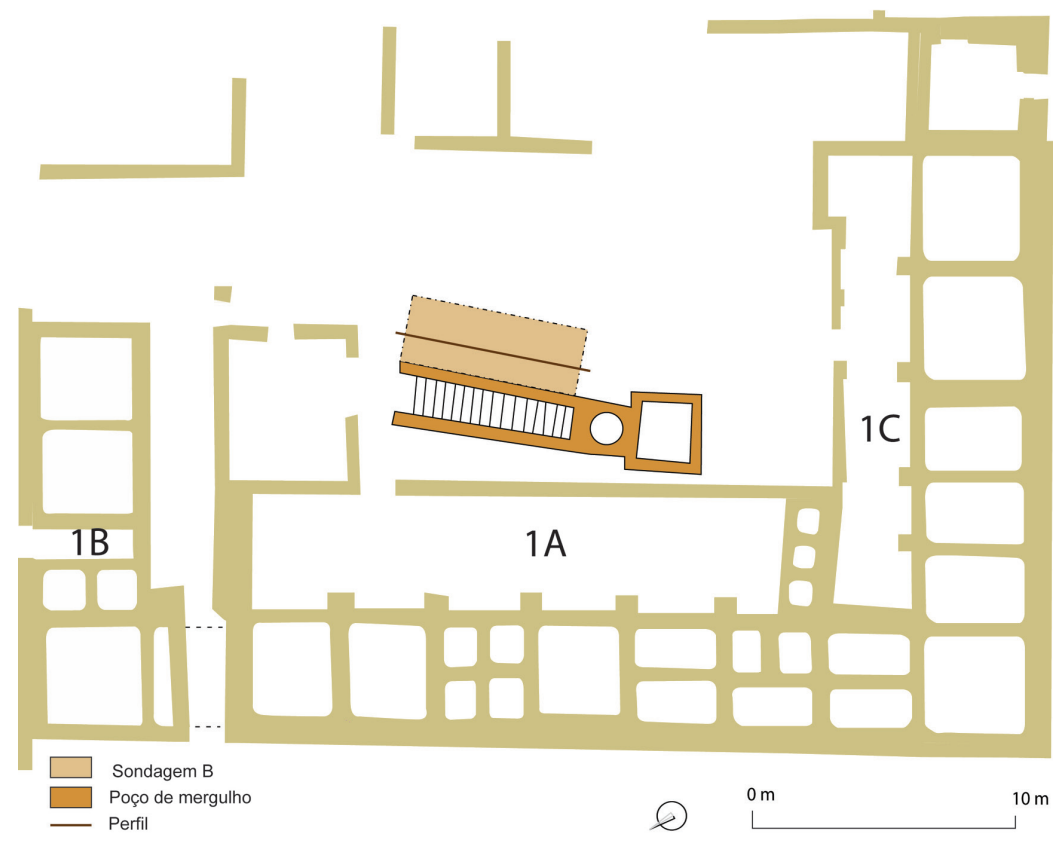

FIG. 3. Oficina 1 com indicação do poço, do perfil e das oficinas $1 A, 1 B, 1 C$ e a localização da sondagem $B$.

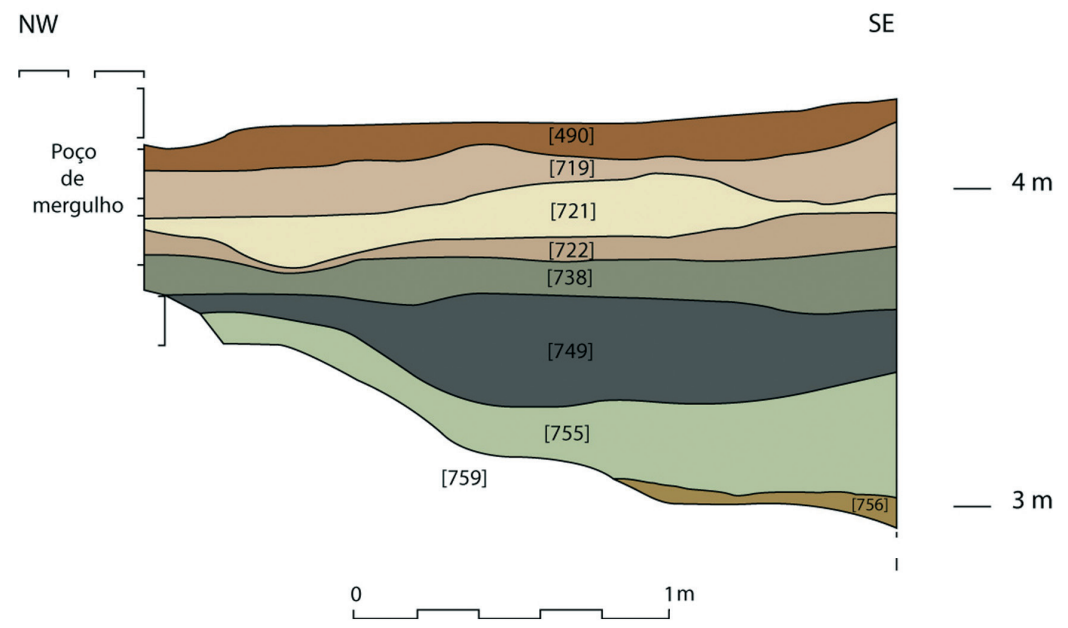

FIG. 4. Corte nordeste da sondagem B. 


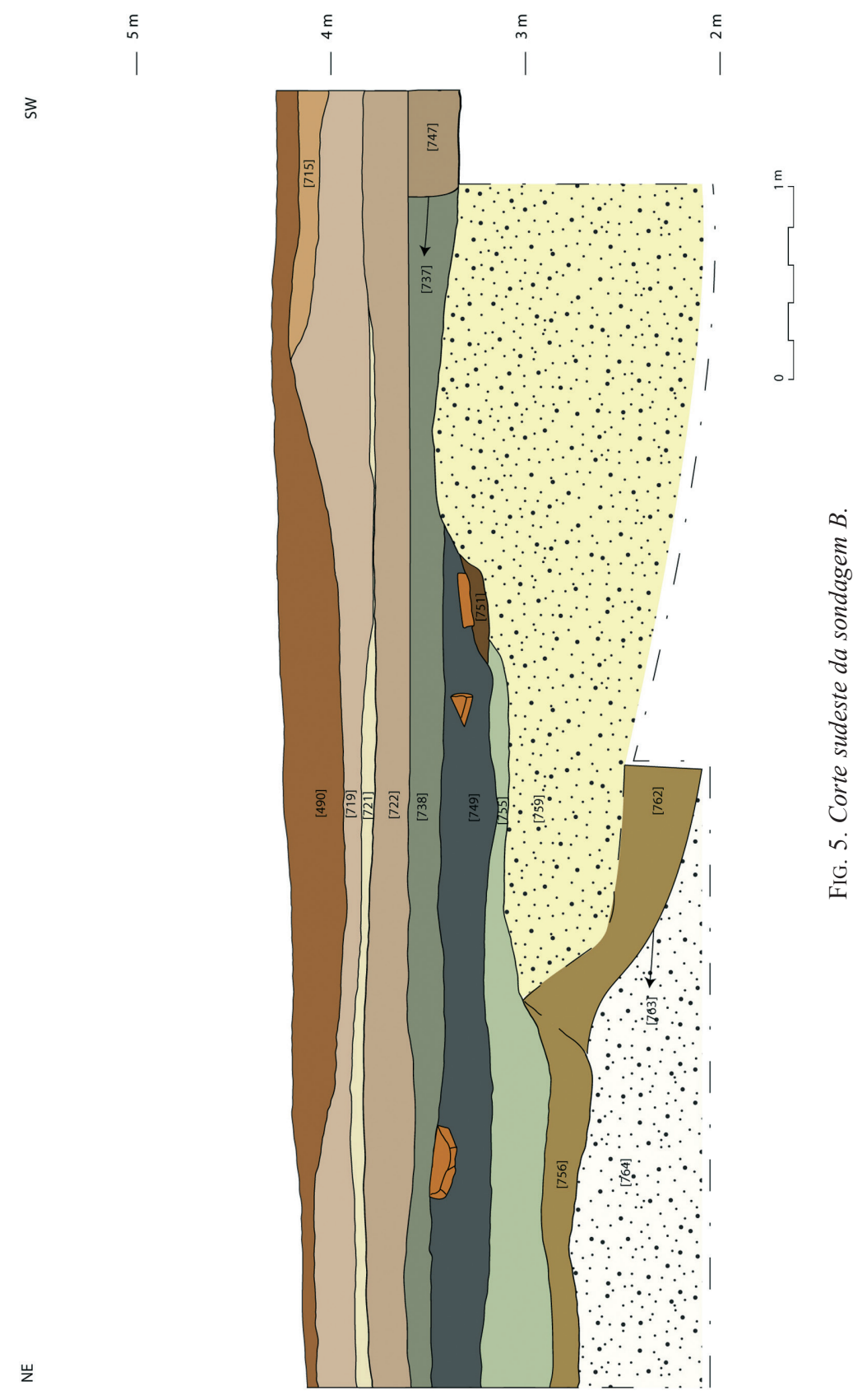




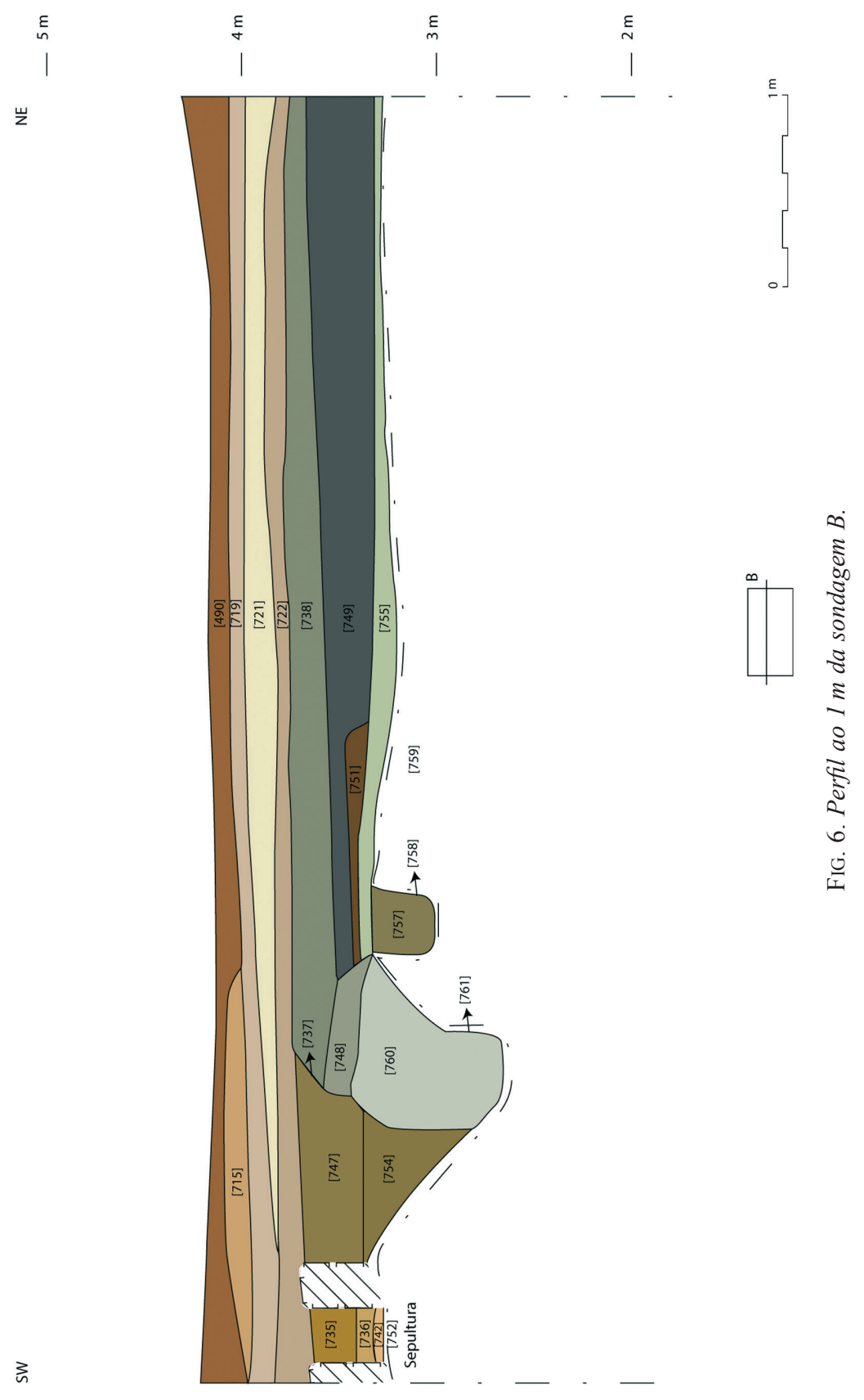




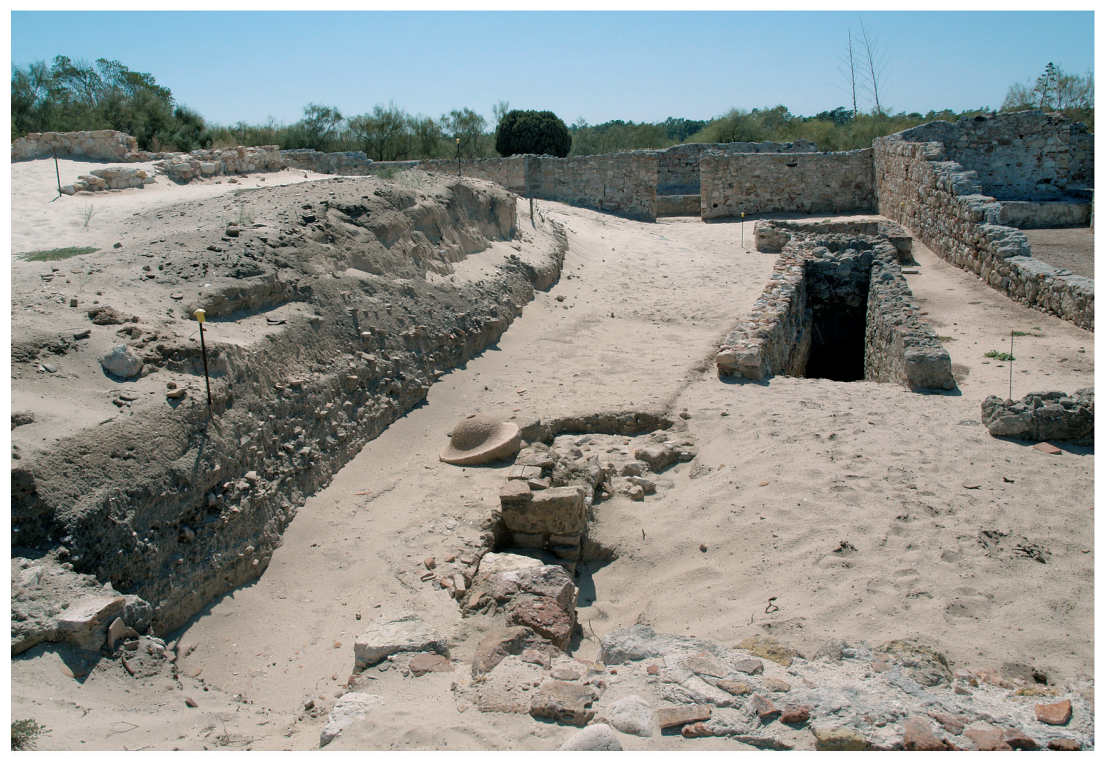

Fig. 7. Poço antes da sondagem.

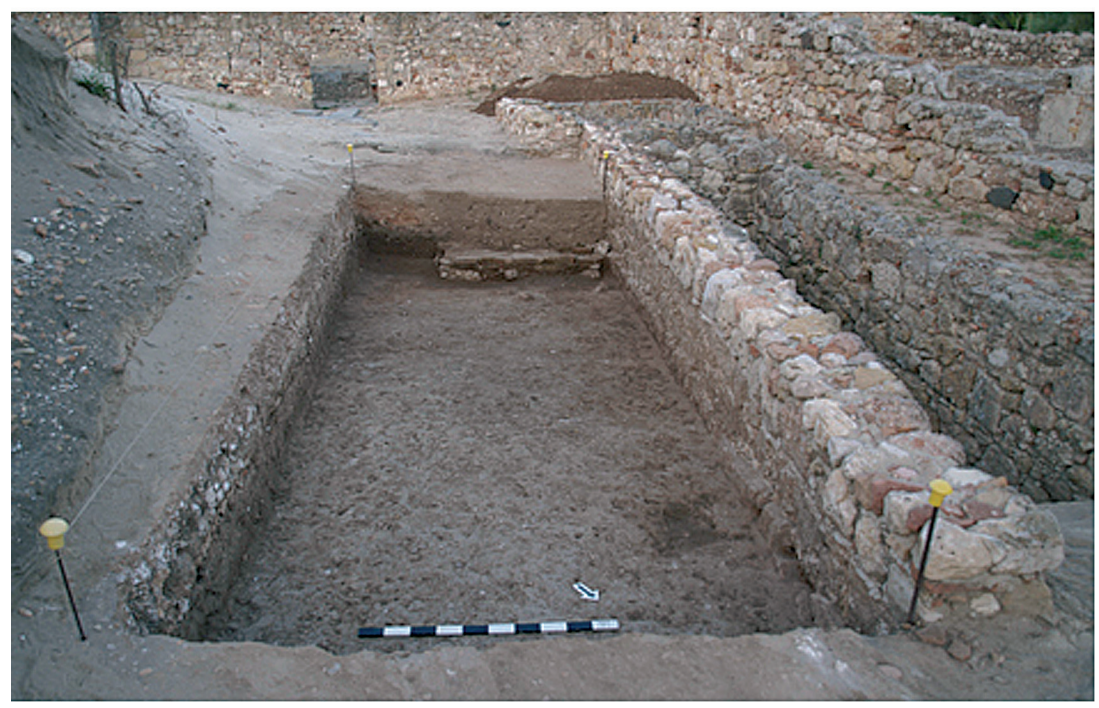

FIG. 8. Aspecto geral do piso [738] e sepultura 4. 


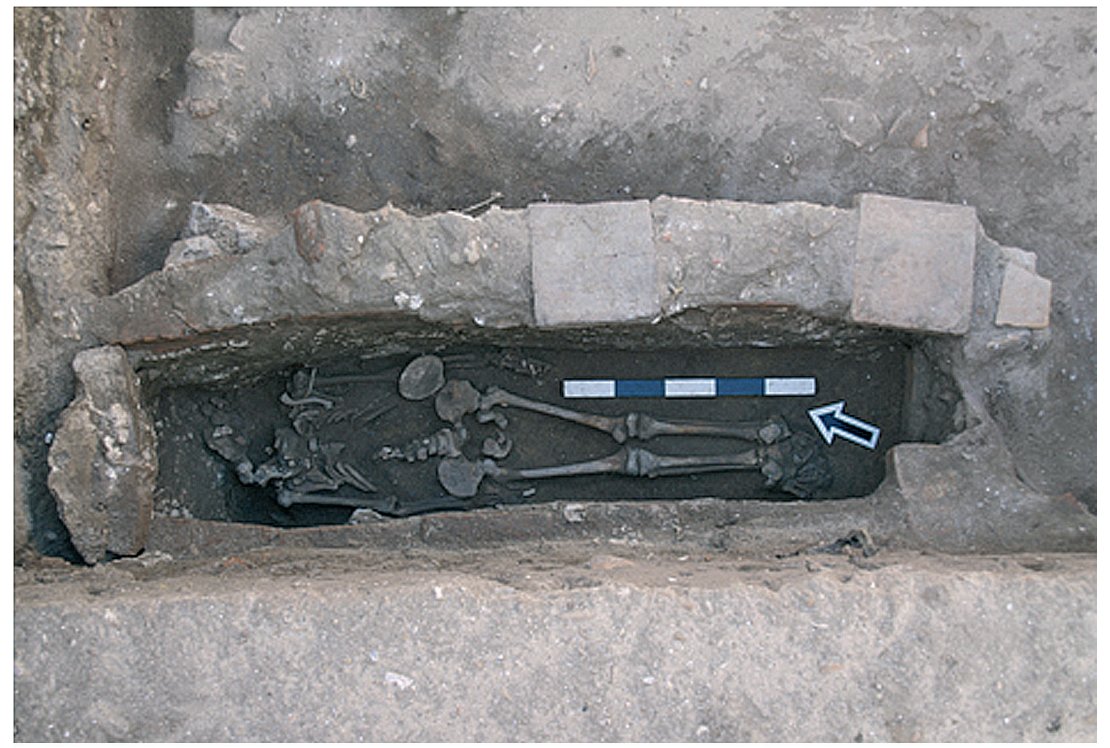

FIG. 9. Sepultura no extremo sudoeste da sondagem.

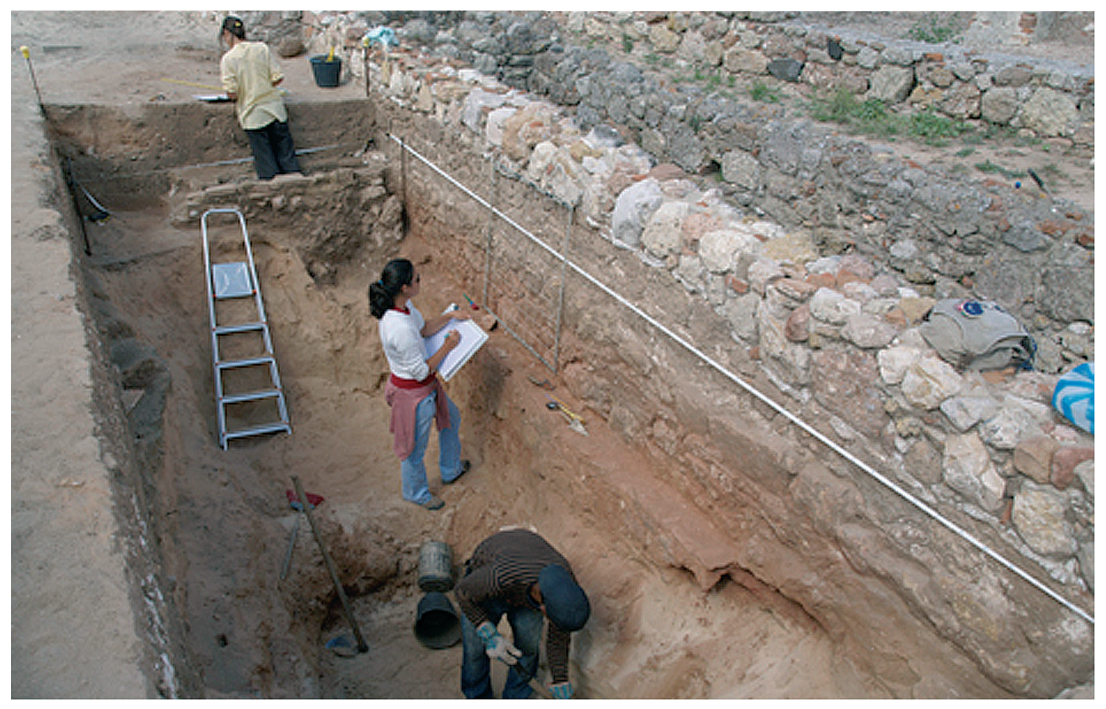

FIG. 10. Aspecto dos trabalhos finais. 
Est. I

[490]
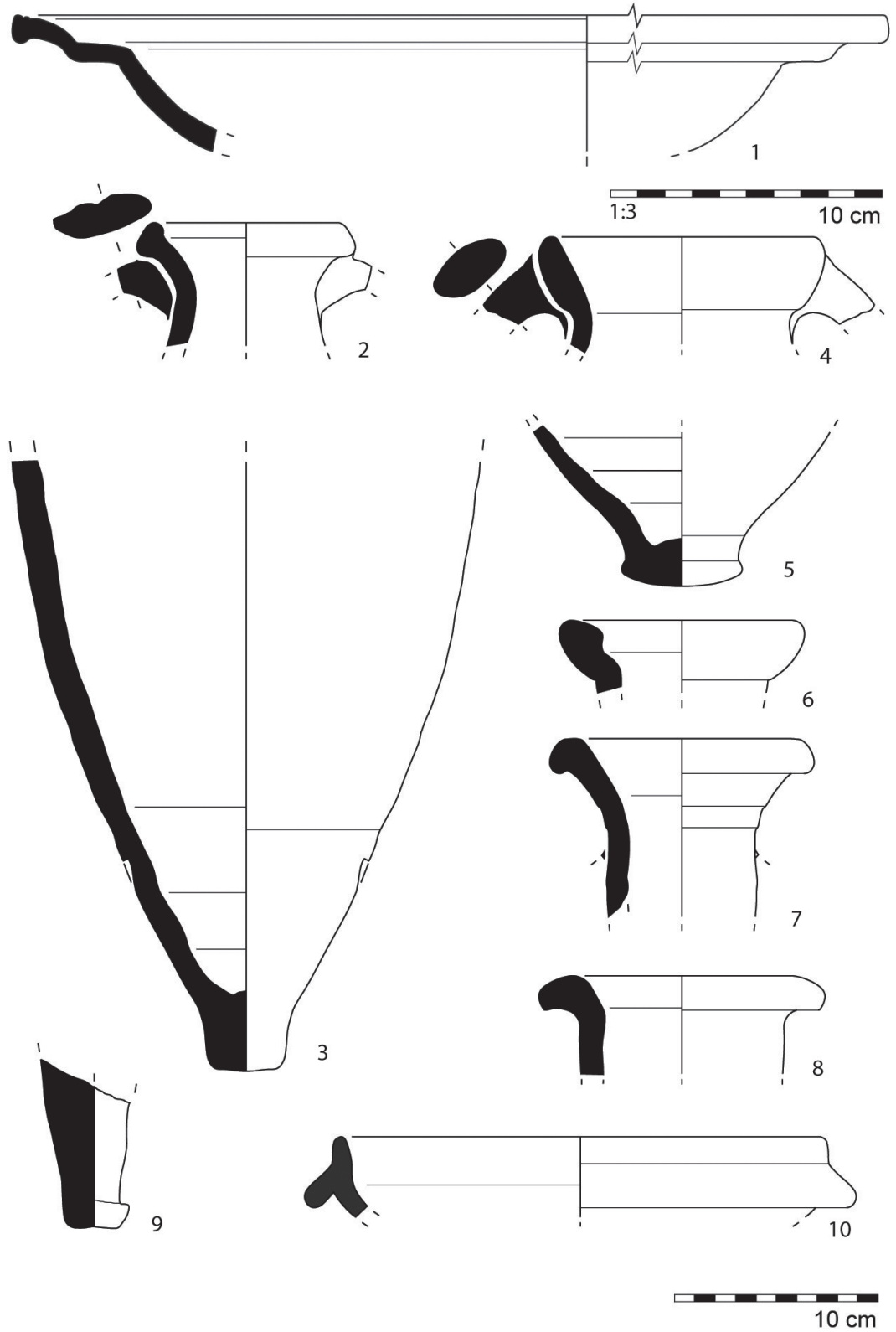
EsT. II

[719]
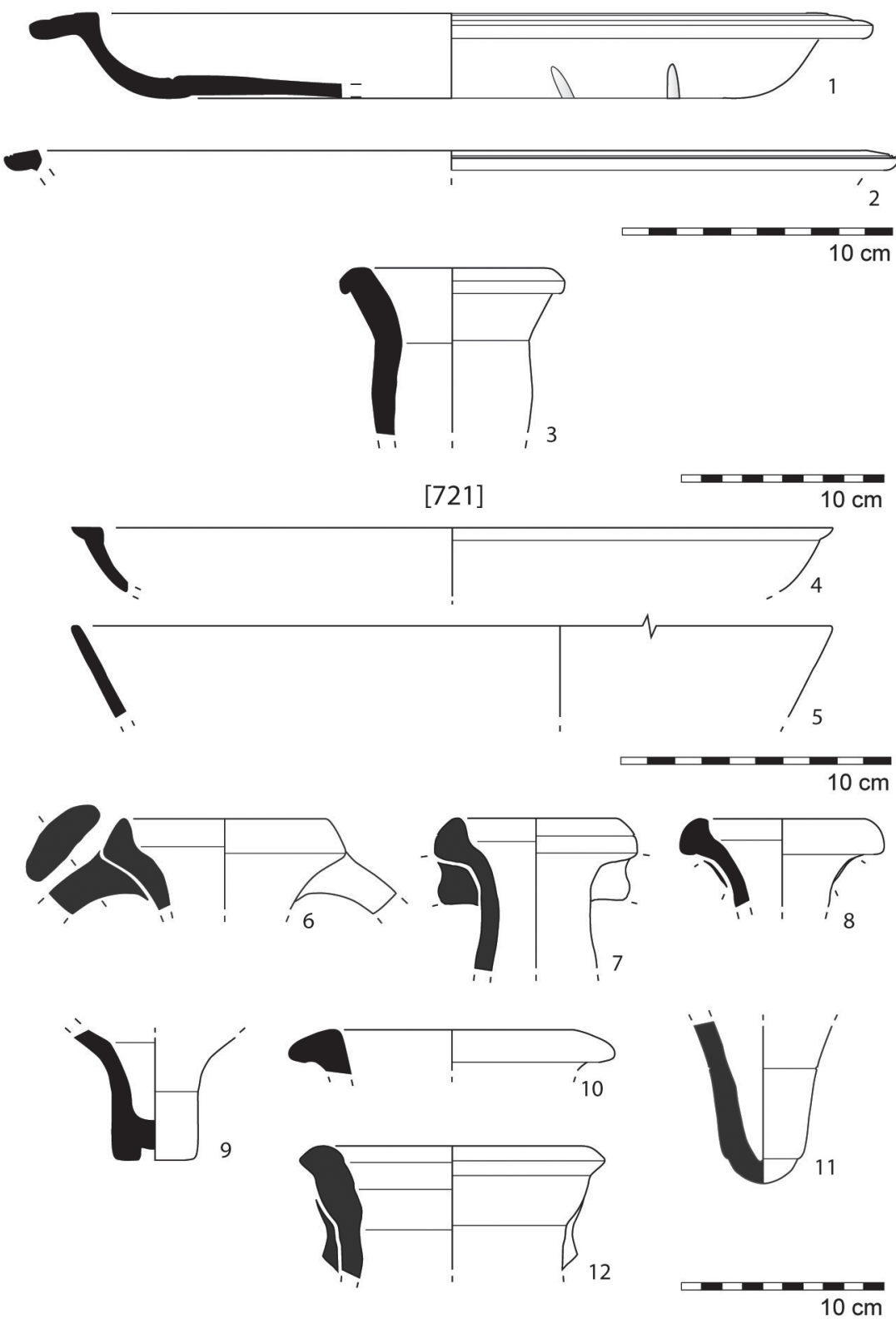
Est. III

[722]
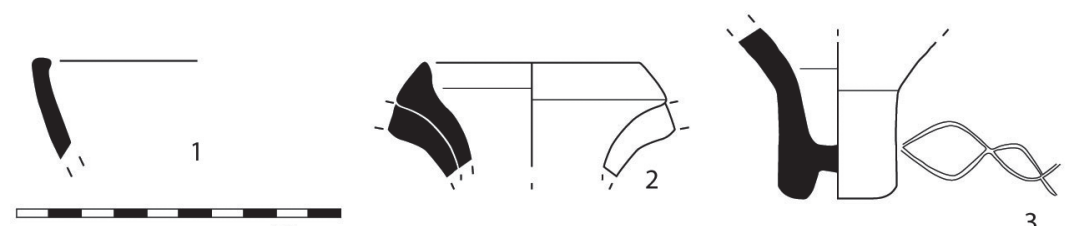

$10 \mathrm{~cm}$
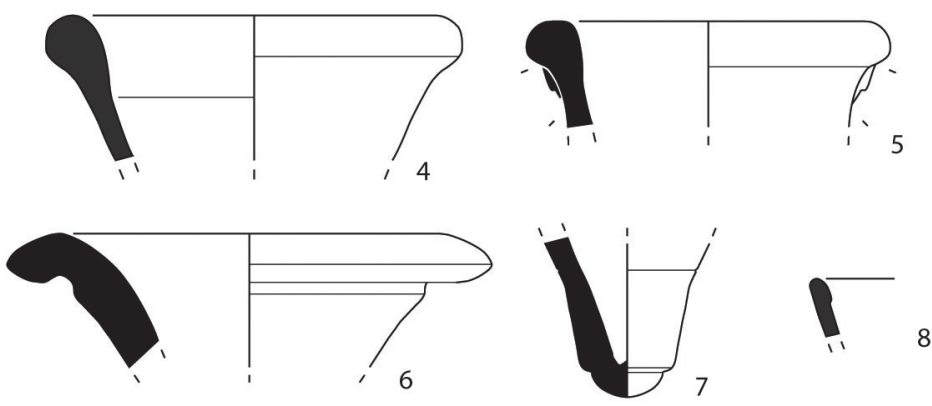

[736]

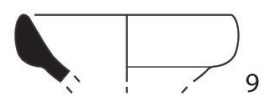

[738]
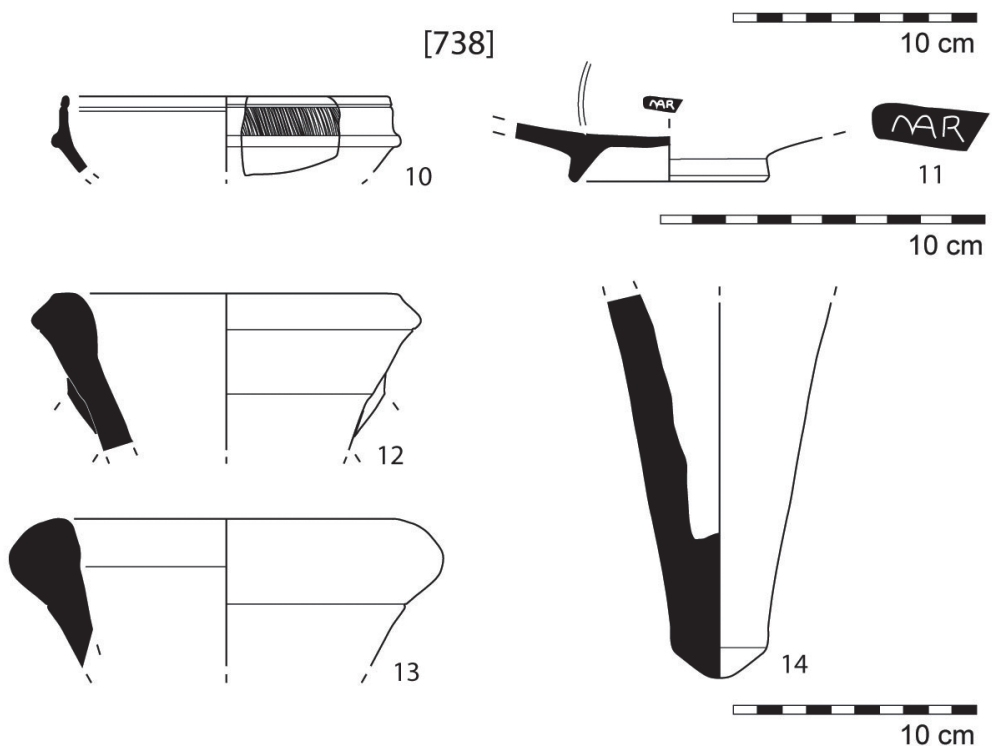
EsT. IV

[749]
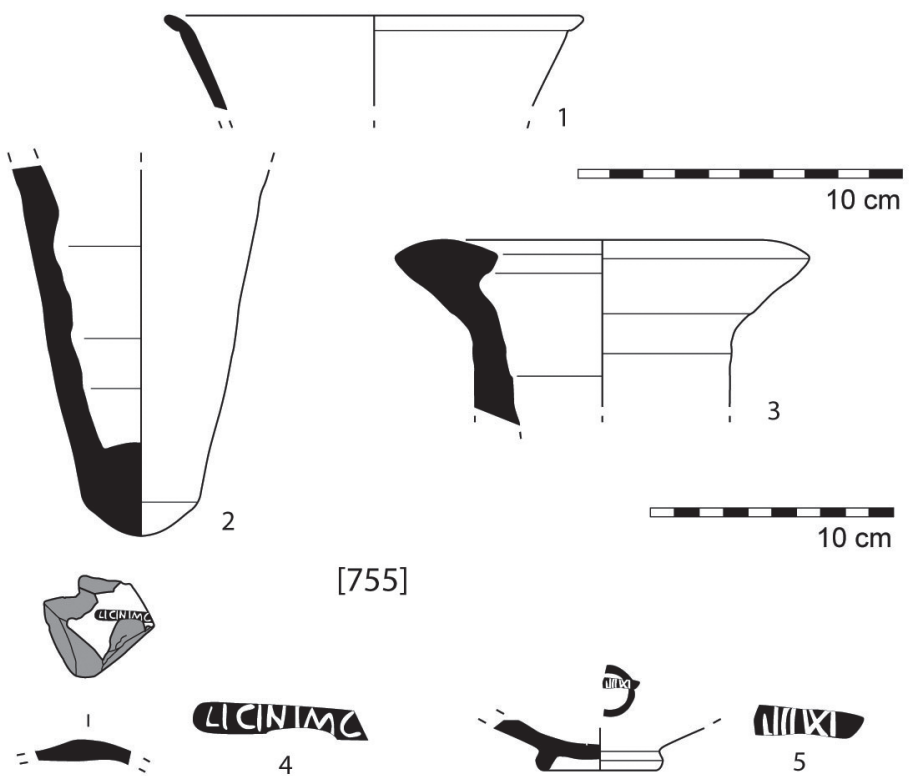

CICINIME

4
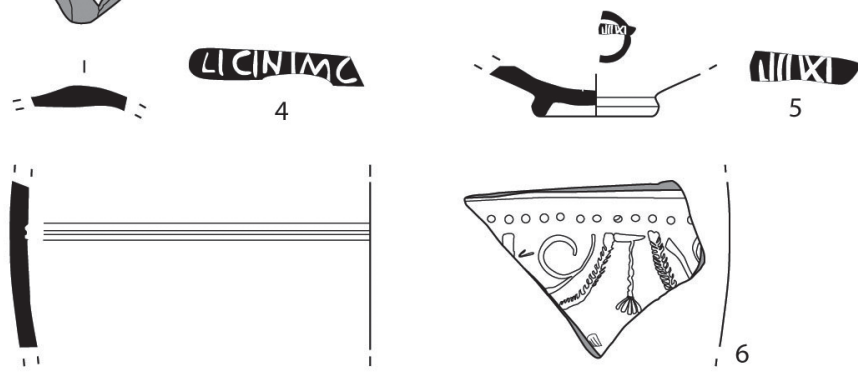

$10 \mathrm{~cm}$

[755]

5
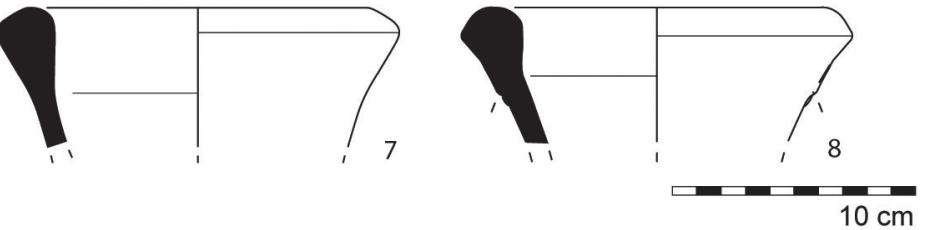

[754]

[759]

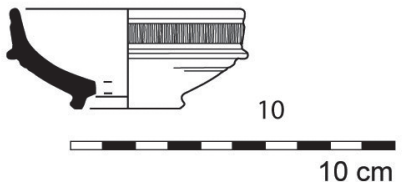


Est. V
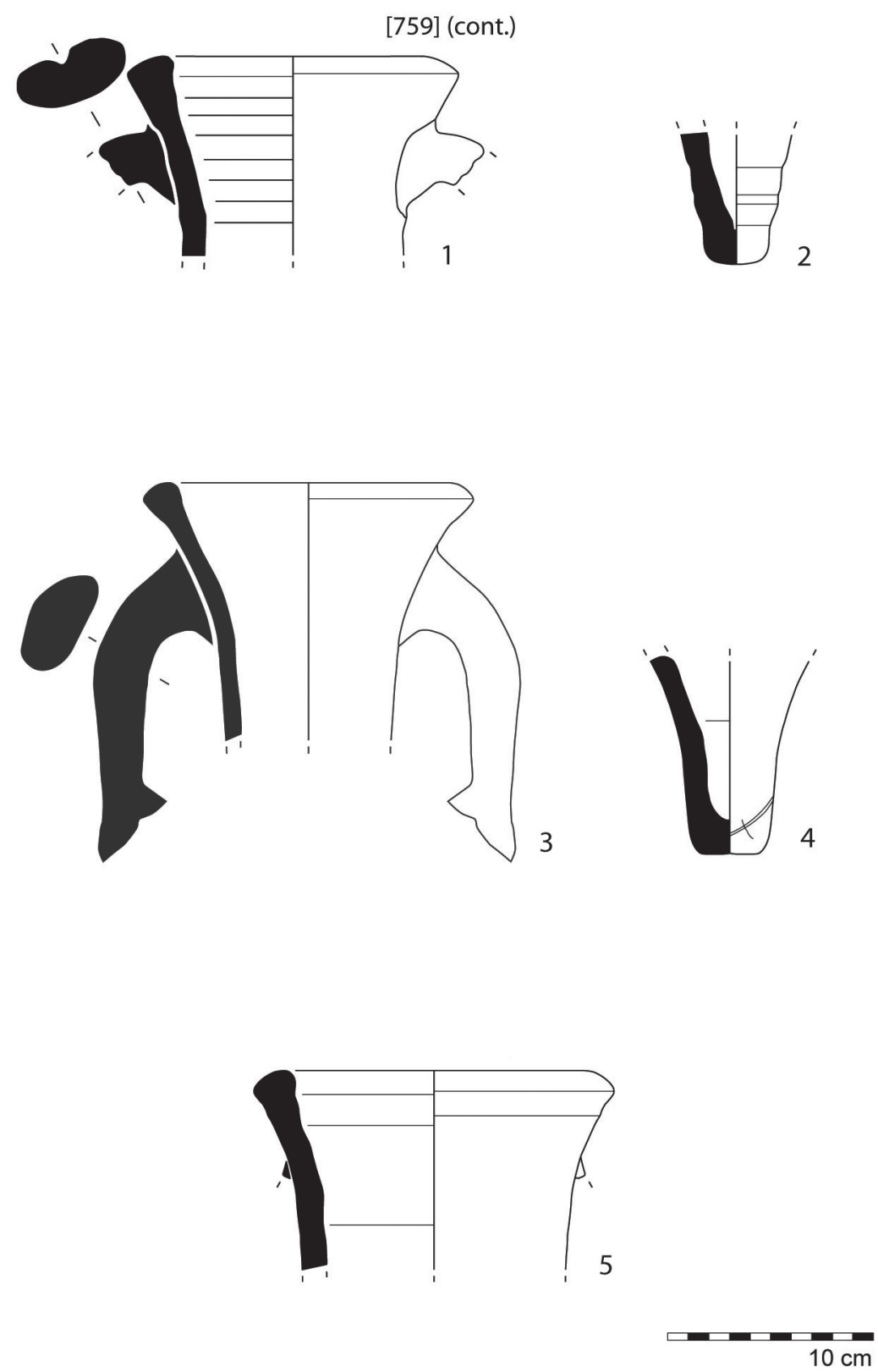